\title{
Reccurent peripheral giant cell granuloma: A case report
}

\section{Nawrotowy nadziąślak olbrzymiokomórkowy - opis przypadku}

\author{
Kamakshi L. N. V. Alekhya ${ }^{D}$, David Kadakampally \\ Manipal College of Dental Sciences, Mangaluru, Karnataka, India \\ A - research concept and design; $\mathrm{B}$ - collection and/or assembly of data; $\mathrm{C}$ - data analysis and interpretation; \\ $\mathrm{D}$ - writing the article; $\mathrm{E}$ - critical revision of the article; $\mathrm{F}$ - final approval of article
}

Dental and Medical Problems, ISSN 1644-387X (print), ISSN 2300-9020 (online)

Dent Med Probl. 2017;54(1):97-100

\section{Address for correspondence}

David Kadakampally

E-mail:david_mahe2005@yahoo.co.in

Funding sources

none declared

Conflict of interest

none declared

Received on 0ctober 1, 2016

Revised on 0ctober 24, 2016

Accepted on November 4, 2016

\begin{abstract}
Peripheral giant cell granuloma is an inflammatory hyperplastic lesion that commonly occurs on peripheral tissues like gingiva, periodontal ligaments or alveolar mucosa. Clinically it is only seen in gingiva, particularly between the first permanent molars and incisors. It manifests itself as a benign tumor consisting of multinucleated giant cells.

This article reports a case of peripheral giant cell granuloma in the left mandibular premolar region in a 34-year-old man. The lesion was excised and sent for histopathological examination, and was diagnosed as peripheral giant cell granuloma. The lesion was recurrent. This case report shows the importance of confirming the diagnosis of the lesion by histopathological examination. Peripheral giant cell granuloma is a reactive lesion that shows a rapid growth rate and can cause minor tooth movement. As the name suggests, there is no bony involvement and the enlargement is a soft tissue extension. Early conservative management will reduce the risk of tooth loss.
\end{abstract}

Key words: peripheral giant cell granuloma, multinucleated giant cells, local trauma

Słowa kluczowe: nawrotowy nadzią́lak olbrzymiokomórkowy, wielojądrowe komórki olbrzymie, uraz miejscowy
DOI

10.17219/dmp/66759

Copyright

○ 2017 by Wroclaw Medical University

and Polish Dental Society

This is an article distributed under the terms of the

Creative Commons Attribution Non-Commercial License

(http://creativecommons.org/licenses/by-nc-nd/4.0/) 
Peripheral giant cell granuloma (PGCG) is among the benign tumors of peripheral origin. It is also referred to as giant cell epulis, peripheral giant cell tumor, osteoclastoma, giant cell hyperplasia or giant cell reparative granuloma. It is an inflammatory hyperplastic lesion that commonly occurs on peripheral tissues like gingiva, periodontal ligaments or alveolar mucosa. As the name indicates, it does not represent a true neoplasm, but rather a reactive hyperplastic lesion secondary to local trauma or irritation. The exact etiology is, however, unknown. ${ }^{1}$

Clinically PGCG is only seen in gingiva, particularly between the first permanent molars and incisors; it presents as a smooth surface, either sessile or pedunculated, bluish red in color. It is asymptomatic, seen as red mass of gingiva composed of fibroblasts and multinucleated giant cells with more nuclei and amorphilic cytoplasm. The giant cells appear to be non-functional in terms of phagocytosis and bone resorption. When it occurs in edentulous areas (which is rare) it produces a cup-shaped radiolucency. It occurs in all age groups, but more commonly in 30- to 40-year-old patients; females have a greater predilection than males. It cannot be clinically separated from pyogenic granuloma. ${ }^{2,3}$

\section{Case report}

A systemically healthy 34-year-old male patient presented with a chief complaint of swelling in the lower left back region for 6 months. His history revealed that the swelling started after chewing on a fish bone 6 months previously and started increasing in size, gradually attaining the present size. There was occasional bleeding from the lesion while brushing. The patient was asymptomatic. Extra-oral swelling was not seen.

On intra-oral examination, an intra-oral swelling was present in the lower left back region, which is illustrated in Fig. 1. A swelling measuring $3 \times 2 \mathrm{~cm}$ was seen adjacent to tooth number 21 (universal tooth numbering system). It was reddish pink in color, with a firm consistency, well defined and non-fluctuant; it was tender on palpation extending along both the buccal and lingual sides of the same tooth. The tooth was vital; it was slightly mobile, but there was no evidence of endodontic pathology associated with it.

A radiological examination revealed horizontal bone loss at tooth 21 but no evidence of bony involvement. Routine blood tests including a complete hemogram, bleeding time and clotting time and erythrocyte sedimentation rate (ESR) were found to be normal.

\section{Treatment of the lesion}

Scaling and root debridement were performed as Phase I therapy. The patient was recalled after one week for a reevaluation. The lesion was excised under local anesthesia (Fig. 2) and sent for histopathological examination.

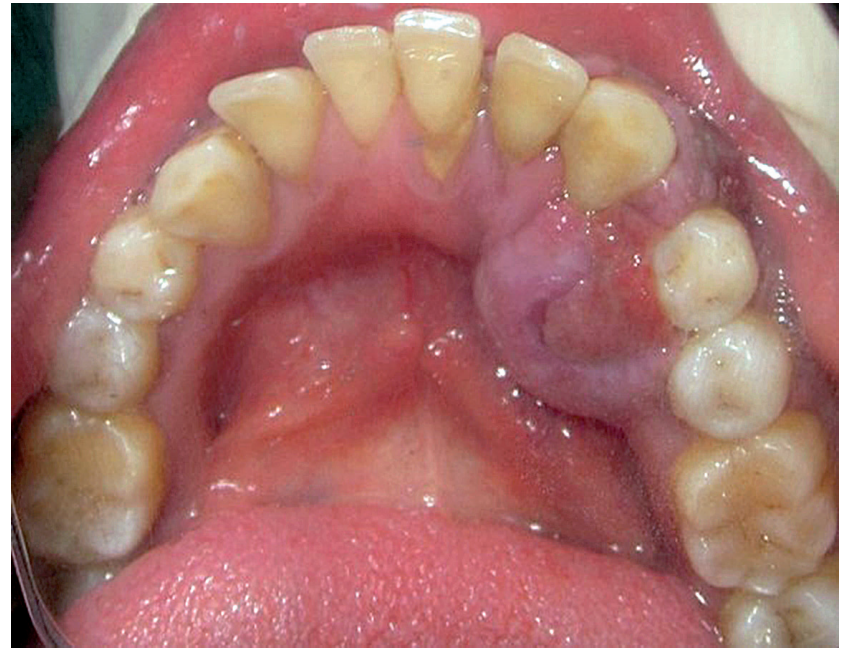

Fig. 1. Pre-operative image showing the intra-oral lesion

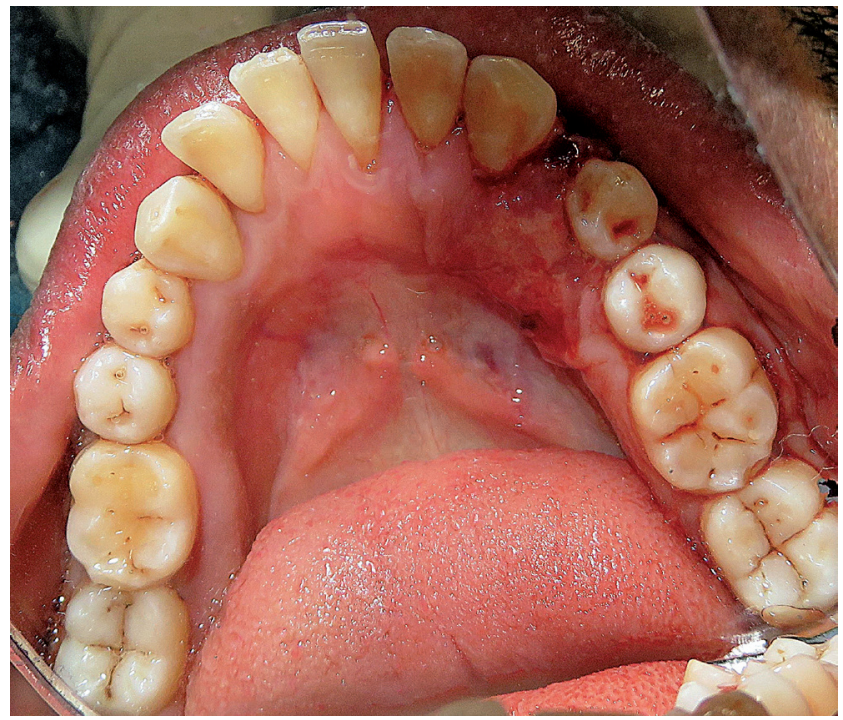

Fig. 2. Post-operative image after excision of the lesion

A routine histological examination with hematoxylin revealed the presence of areas of multinucleated giant cells with 6 to 8 nuclei and amorphilic cytoplasm in a background of plump ovoid and spindle shaped mesenchymal cells. Deposition of hemosiderin pigments along with collagen fibers intermixed with chronic inflammatory cell infiltrate (chiefly lymphocytes and plasma cells), blood vessels engorged with RBCs and areas of hemorrhage were also seen. The zone of giant cell proliferation was delineated from the overlying hyperplastic parakeratinized stratified squamous epithelium by a zone of normal lamina propria. The histological picture is shown in Fig. 3.

The diagnosis was suggestive of peripheral giant cell granuloma. A characteristic feature of PGCG is recurrence, which is seen in $5-11 \%$ of cases. ${ }^{4}$ Recurrence of peripheral giant cell granuloma was observed in the present case after 3 months. 


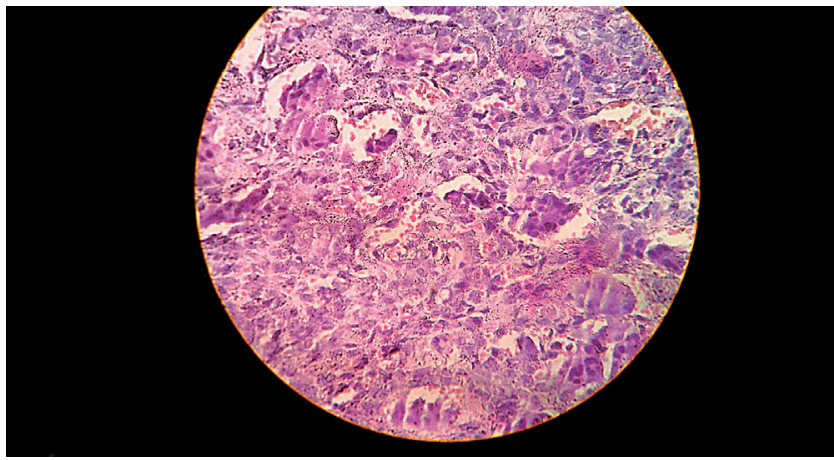

Fig. 3. Histological picture showing multinucleated giant cells and foci of hemorrhage

\section{Discussion}

Peripheral giant cell granuloma is the most common lesion in both jaws. The etiology of PGCG is still not clear. The literature indicates that PGCG has a female predilection, although the present case report concerns peripheral giant cell granuloma in a male patient, which is similar to the study by Bhaskar et al. ${ }^{5}$

Radiographic features in an edentulous area include cup-shaped resorption of alveolar bone that is called a "levelling effect"; and in a dentate region there will be widening of the periodontal ligament space and resorption of the alveolar crest in the interdental region. ${ }^{6}$

Bischof et al. reported a case of peripheral giant cell granuloma associated with implants. ${ }^{7}$

The observed recurrence of this lesion is from $5 \%$ to $11 \%$. In the present case, recurrence was seen after 6 months, which coincides with a case report by Prabhat. ${ }^{8}$ To prevent recurrence, the excision of the lesion should be performed down to the periosteum. In the present case, total excision and complete removal of the remnants of the lesion was advised to prevent recurrence.

Rodrigues et al. reported that the presence of lesions may cause mobility or displacement of neighboring teeth. ${ }^{1}$ In the present case, increased mobility of the tooth was noted after excision of the lesion. It was painless and it did not interfere with occlusion, hence it was not affected by traumatic forces. Rodrigues et al. also stated that the consistency of a PGCG lesion depends on its age: with time, there is an increase in collagen fibers, so a mature lesion is firm in consistency. ${ }^{1}$ In the present case, the consistency was firm.

El Mofty et al. stated that these giant cells are derived from bone marrow mononuclear cells and are present in the stroma only in response to an unknown stimulus. ${ }^{9}$ The giant cells are short-lived and disappear early in cultures, in contrast to the stromal cells, which show active proliferation. ${ }^{9}$

Willing et al. reported that factors that are secreted by stromal cells, such as monocyte chemo attractant pro- tein-1 (MCP1), osteoclast differentiation factor (ODF) and macrophage-colony stimulating factor (M-CSF), are monocyte chemo attractants and are essential for osteoclast differentiation. This suggests that the stromal cells stimulate the immigration of monocytes from the blood into the tumor tissue and enhance their fusion into osteoclast-like, multinucleated giant cells. ${ }^{2}$ As Abe et al. wrote, "the recently identified membrane-bound protein family, a disintegrin and metalloprotease (ADAM), is considered to play a role in the multinucleation of osteoclasts and macrophage-derived giant cells from mononuclear precursor cells".

There are no pathognomic clinical features that differentiate the peripheral giant cell granuloma from pyogenic granuloma, peripheral ossifying fibroma or giant cell fibroma. Along with clinical examinations, radiographic and histological examinations are needed to confirm the diagnosis. ${ }^{11-13}$

\section{Conclusions}

Even though the etiology is unclear, poor oral hygiene could be a predisposing factor in PGCG. Early diagnosis and conservative management is important in such lesions, since they can become more destructive over time. Peripheral giant cell granuloma can manifest as gingival enlargement, which is a reactive lesion with a rapid growth rate and involvement of soft tissue above underlying bone, without any central bony lesion. This could cause minor to moderate tooth movement because of resorption of underlying alveolar bone. Therefore, early management of these lesions can prevent the risk of tooth loss.

\section{References}

1. Rodrigues SV, Mitra DK, Pawar SD, Vijayakar HN. Peripheral giant cell granuloma: This enormity is a rarity. J Indian Soc Periodontol. 2015;19:466-469.

2. Willing M, Engels C, Jesse N, Werner M, Delling G, Kaiser E. The nature of giant cell tumor of bone. J Cancer Res Clin Oncol. 2001;127: 467-474.

3. Agarwal A, Prasad UC, Jithendra KD. Peripheral giant cell granuloma: A case report and review of literature. Guident.net/periodontics. 2011,16.

4. Khan KP, Gokhale ST, Manjunath RGS, Bhattacharya HS. Recurrent peripheral giant cell granuloma - a rare case report. Indian J Dent Sci. 2014;6:50-52.

5. Bhaskar SN, Cutright DE, Beasley JD, Perez B. Giant cell reparative granuloma (peripheral): Report of 50 cases. J Oral Surg. 1971;29: 110-115.

6. Flaitz CM. Peripheral giant cell granuloma: A potentially aggressive lesion in children. Pediatr Dent. 2000;22:232-233.

7. Bischof M, Nedir R, Lombardi T. Peripheral giant cell granuloma associated with a dental implant. Int J Oral Maxillofac Impl. 2004;19: 295-299.

8. Prabhat. MPV. Recurrent peripheral giant cell granuloma of the gingiva - a case report. Ann Essenc Dent. 2010;2:65-67.

9. Ei-Mofty SK, Osbody P. Growth behavior and lineage of isolated and cultured cells derived from giant cell granuloma of the mandible. J Oral Pathol. 1985;14:539-552. 
10. Abe E, Mocharla H, Yamate T, Taguchi Y, Monolages SC. Meltrinalpha, a fusion protein involved in multinucleated giant cell and osteoclast formation. Calcified Tissue Internat. 1999;64:508-515.

11. Adlakha VK, Chandna P, Rehani U, Rana V, Malik W. Peripheral giant cell granuloma. J Indian Soc Pedodont Prevent Dent. 2010;4:293-296.
12. Sahingur $\mathrm{SE}$, Cohen RE, Aguirre A. Esthetic management of peripheral giant cell granuloma. J Periodontol. 2004;75:487-492.

13. Ghimire N, Nepal P, Ghimire N. Peripheral giant cell granuloma: A case report. J Chitwan Medical College 2013;3:28-30. 